\title{
Early Onset Neonatal Sepsis; Diagnostic Value of Some Laboratory Tests
}

\author{
Sepsis neonatal de inicio temprano; Valor diagnóstico \\ de algunas pruebas de laboratorio
}

Tania Soledad Licona Rivera'; German Edgardo Fajardo Dubón²; Rubén Arturo Ferrera García² \& Alejandra Mazariegos ${ }^{3}$

LICONA, R. T. S.; FAJARDO, D. G. E.; FERRERA, G. R. A. \& MAZARIEGOS, A. Early onset neonatal sepsis; Diagnostic value of some laboratory tests. Int. J. Med. Surg. Sci., 4(1):1109-1114, 2017.

SUMMARY: Early Onset Neonatal Sepsis (EONS) is a clinical situation resulting from the invasion and proliferation of bacteria, fungi or viruses in the newborn (NB) bloodstream, which occurs within the first 72 hours of life. To determine the diagnostic usefulness of laboratory tests performed on infants with suspicion of early neonatal sepsis at the Santa Barbara Integrated Hospital, Honduras. A case-control study was carried out during 2016; the cases were 20 infants with early onset neonatal sepsis, and the controls were 40 infants who were admitted as potentially septic, but the blood culture result was negative. Sensitivity, specificity, positive predictive value (PPV) and negative (NPV) of leukocytosis, platelets, initial C-reactive protein (CRP) and control were calculated. Data were analyzed with SPSS version 19. It was found that $17(28.3 \%)$ NB were women and $43(71.7 \%)$ were men. The VPP of the initial PCR was $5 \%$, increasing to $85 \%$ in the control study. The isolated microorganism was enterobacter in $6(30 \%)$ of the RNs. Of the $23(38.3 \%)$ neonates who presented complications; 11 (48 \%) had positive blood culture and $12(52 \%)$ had negative blood cultures. The discharge condition was medical discharge in $55(92 \%)$ and referred to a more complex hospital $5(8 \%)$ of the neonates. The VPP of the C-reactive protein increases considerably when doing a laboratory control, between 24-48 hours.

KEY WORDS: Laboratories; Newborn; Sepsis.

\section{INTRODUCTION}

The septic response is an extremely complex chain of events it involves inflammatory and anti-inflammatory processes, humoral and cellular reactions and circulatory abnormalities. The diagnosis of sepsis and the assessment of its severity are complicated by the highly variable and non-specific nature of the signs and symptoms of sepsis. However, the diagnosis and stratification of the severity of sepsis is important, increasing the possibility of initiating specific treatment (Swarnkar \& Vagha, 2013). EONS occurs in the newborn within the first 72 hours of life (Secretaria de Salud de Honduras, 2010).
Each year there are four million neonatal deaths in the world and $35 \%$ are due to infectious processes. In the United States of America, the incidence of EONS is estimated to be 1 to 2 cases per 1,000 live births; however, in developing countries it ranges from 2.2 to 9.8 events per 1,000 live births (Pérez et al., 2015).

Microorganisms that cause EONS are typically colonizers of the maternal genitourinary tract, leading to infection of the amniotic fluid, placenta, cervix or vaginal canal, the pathogen may ascend due to rupture of the amniotic

\footnotetext{
${ }^{1}$ Pediatrician, Santa Barbara Integrated Hospital. Faculty, University School of Health Sciences, National Autonomous University of Honduras, Sula Valley. EUCS, UNAH-VS, Honduras.

2 Resident, Internal Medicine program, National Autonomous University of Honduras, Honduras.

3 Medical Doctor, graduated from the National Autonomous University of Honduras, Honduras.

${ }^{4}$ Medical Doctor, Hospital Santa Bárbara Integrated, Honduras.
} 
membranes. The infant can acquire the pathogen either in utero or intrapartum. Risk factors for EONS may be maternal or neonatal; during childbirth, maternal risk factors include rupture of membranes, fever, vaginal colonization, low socioeconomic status, malnutrition, among others. The adequacy of the maternal immune response is an important risk factor for septicemia. Neonatal factors include prematurity / birth with low birth weight, male gender, congenital anomalies, complicated or instrumented delivery, and APGAR score of 6 or less at 5 min (Simonsen et al., 2014).

Group B streptococcus (GBS, Streptococcus agalactiae) is an encapsulated gram-positive bacterium and remains the leading cause of EONS. Escherichia coli (E. coll) is the major pathogen of EONS in preterm infants and the second most common cause in neonates. Term neonates, is frequently associated with severe infections and meningitis; GBS and $E$. coli together account for approximately $70 \%$ of cases in the neonatal period. (Stoll et al., 2011). Although less frequent, Listeria monocytogenes is associated with invasive disease in the newborn, spontaneous abortion or fetal death if acquired during pregnancy (Birju \& Padbury, 2014).

The purpose of this study was to determine the diagnostic utility of laboratory tests performed on infants with suspicion of early neonatal sepsis at the Santa Barbara Integrated Hospital, Honduras.

\section{MATERIAL AND METHOD}

A quantitative case-control study was performed in the neonatal ward of Santa Barbara Integrated Hospital during the year 2016. Twenty cases and 40 controls were analyzed, with a $1: 2$ ratio. Case definition of neonates with early neonatal sepsis confirmed by positive blood cultures and controls infants who were admitted as potentially septic but with negative blood cultures. Pathological reference values for leukocytes, Protein C Reactive and platelets were taken as described in the norms of the Ministry of Health of Honduras; Leukocytosis: leukocytes greater than $20,000 \mathrm{c} / \mathrm{mm}^{3}$ in peripheral blood.
Thrombocytopenia: Thrombocytes less than $100,000 \mathrm{c} / \mathrm{mm}^{3}$. Abnormal PCR is one that presents values greater than $10 \mathrm{mg} / \mathrm{dl}$. Initial PRC is performed in the first 24 ho to the newborn with suspicion of sepsis, and at $48 \mathrm{~h}$ a control. The information was obtained directly from the clinical records through an instrument containing 16 questions; Sociodemographic data, laboratory results, final diagnosis and egress condition. The database was performed in the SPSS version 19 program. For the analysis of the data, we calculated positive predictive value, negative predictive value, sensitivity and specificity.

\section{RESULTS}

Maternal age ranged from $15-40$ years, with a mean of 25.9 and a standard deviation of 7.73 . In 56 (93\%) of the files, the civil status was not recorded. One patient, $1.6 \%$, was married and three (5\%) were unmarried.

In relation to the number of pregnancies of the mother; $24(40 \%)$ were their first pregnancy, $10(16.7 \%)$ second, $9(15 \%)$ were their third and $17(28.3 \%)$ had a history of 4 or more pregnancies.

It was found that $16(26.7 \%)$ mothers had an incomplete primary education level and $9(15 \%)$ were illiterate (Table I).

Regarding the provenance of the mothers; $48(80 \%)$ were from the department of Santa Barbara, 9 (15\%) from Lempira, 1 (1.7\%) from Comayagua and 2 (3.3\%) from the Cortes. The level of Health Service, where the mothers received prenatal care, was: $3(5 \%)$ in Public Hospital, $1(1.7 \%)$ at private level, $50(83.3$ $\%)$ in Health Center with physician, 2 (3.3\%) controlled their pregnancy in the Rural Health Center and $4(6.7 \%)$ did not control pregnancy.

Regarding the sex of the newborns, 17 (28.3 $\%)$ were women and $43(71.7 \%)$ were men.

When analyzing the usefulness of the laboratory studies, it was found that the PPV of the initial PCR was $5 \%$, increasing to $85 \%$ in the control study.(Tabla II). 
Of the 20 newborns with proven infection by blood culture, in 6 (30\%), the isolated microorganism was Enterobacter (Fig. 1).

Of the 60 newborns, $23(38.3 \%)$ presented complications; 11 (48\%) presented in the NB that had a positive blood culture result and $12(52 \%)$ of the complications occurred in the group with negative blood culture (Table III).

The discharge condition was medical discharge in $55(92 \%)$ and referred to a more complex hospital 5 ( $8 \%$ ) of the neonates. None died in the Santa Barbara Integrated Hospital.

Table I. Educational level of mothers.

\begin{tabular}{lll}
\hline Educational level & Numbers & $(\%)$ \\
\hline Illiterate & 9 & $15 \%$ \\
Incomplete primary education level & 16 & $26.7 \%$ \\
Complete primary education level & 15 & $25 \%$ \\
Incomplete secundary education level & 4 & $6.7 \%$ \\
Complete secundary education level & 1 & $1.7 \%$ \\
University Graduated & 1 & $1.7 \%$ \\
Not recorded & 14 & $23.3 \%$ \\
Total & 60 & 100 \\
\hline
\end{tabular}

Table II. Negative predictive value, positive predictive value, sensitivity and specificity.

\begin{tabular}{lcccc}
\hline Laboratory Exam & $\begin{array}{c}\text { CPPV } \\
(\%)\end{array}$ & $\begin{array}{c}\text { dNPV } \\
(\%)\end{array}$ & $\begin{array}{c}\text { Sensibility } \\
(\%)\end{array}$ & $\begin{array}{c}\text { Specificity } \\
(\%)\end{array}$ \\
\hline Leukocytes greater than $20,000 / \mathrm{mm}^{3}$ & 45 & 69 & 25 & 85 \\
Thrombocytes less than $100,000 / \mathrm{mm}^{3}$ & 9 & 81.6 & 5 & 100 \\
aInitial CPR (+) & 5 & 57.5 & 5.5 & 54.7 \\
bControl CPR (+) & 85 & 25 & 94 & 77 \\
\hline
\end{tabular}

aInitial CRP: C- reactive protein in the first 24 hours of life. bCPR control: C-reactive protein between 24-48 hours of life. cPPV: Positive predictive value. dNPV Negative predictive value.

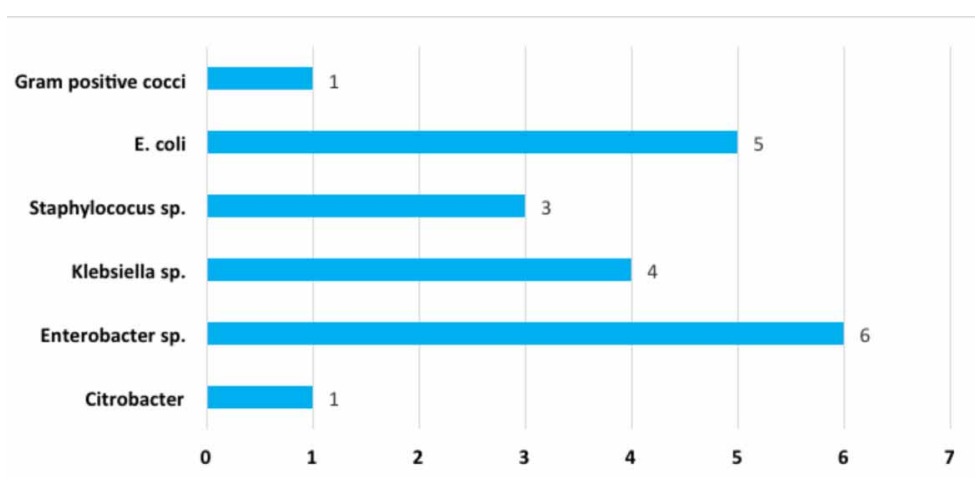

Fig. 1. Microorganisms isolated from blood cultures.

Table III. Complications in newborns

\begin{tabular}{lcc}
\hline Complication & \multicolumn{2}{c}{ Blood culture result } \\
& Positive & Negative \\
\hline Septic shock & 5 & 6 \\
*DIC & 6 & 5 \\
Ventilatory failure & 0 & 1 \\
Total & 11 & 12 \\
\hline
\end{tabular}

*DIC: Disseminated intravascular coagulation

\section{DISCUSSION}

Infection in neonates continues to be a public health problem with significant morbidity and mortality. Timely diagnosis is vital to prevent serious complications in neonates. In an investigation carried out by (Licona et al., 2016), at Santa Barbara Integrated Hospital, a prevalence of $60.6 \%$ of early neonatal sepsis was found among outpatient diagnoses.

The diagnosis of EONS continues to be a challenge, since clinical manifestations are variable and at the same time nonspecific of infection. In some cases as in preterm infants, they may be asymptomatic and base the 
diagnostic suspicion in the mother's birth records or in the newborn's own history. According to the Ministry of Health of Honduras (2011), the three fundamental pillars for diagnosis are: a) To recognize maternal, fetal or both risk factors for the development of early neonatal sepsis, as well as other Birth. B) Clinical evolution and evaluation, recognizing signs and symptoms that suggest infection and c) lab and cabinet examinations.

An ideal biomarker needs to have a high degree of precision in the presence or absence of a definitive infection at an early stage, to guide the initiation and duration of antibiotic therapy. The diagnostic utility of the following biomarkers appears to be the most practical; in the early phase (interleukin IL-6, IL-8, tumor necrosis factor alpha, neutrophil CD64), median (procalcitonin) and late (C-reactive protein) (Bhandari, 2014). In Santa Barbara Integrated Hospital there are no procalcitonin, interleukin 6 , immunoglobulin $M$, due to the lack of a budget. Lumbar puncture is performed in newborns with high suspicion of neurological infection.

The most frequently performed laboratory studies are complete blood count, absolute neutrophil count, proportion of immature and total neutrophils, and C-reactive protein. (Mally et al., 2014) However, in the Hospital where this investigation was conducted, immature neutrophil counts are not performed, limiting the possibility of calculating the proportion between immature and total neutrophils.

However, not all of these tests ensure accurate diagnosis as some of the reference values, such as white blood cell count, have little sensitivity and specificity. Likewise, platelet count has been characterized by poor sensitivity and specificity, unlike recent studies suggesting that the ratio between immature neutrophils and total neutrophils has a higher specificity in sepsis. (Arunachalam \& Pammi, 2015). In this investigation, the leukocyte count was higher than $20,000 / \mathrm{mm}^{3}$, presented a PPV of $45 \%$, a NPV of $69 \%$, a sensitivity of $25 \%$ and a specificity of $85 \%$ and a Thrombocytes count of less than 100,000 / $\mathrm{mm}^{3}$ showed $9 \%$ PPV, $81.6 \%$ NPV, $5 \%$ sensitivity and $100 \%$ specificity, all of which indicate that the hemogram allows us to easily detect healthy babies. However, in order to detect EONS infants, they are not very useful. Which we need to rely on other diagnostic tests.

C-reactive protein is one of the tests that has been most studied as a diagnostic method for neonatal sepsis. Although it presents a low sensitivity in the beginning of the infectious process, its diagnostic value improves when serial measurements are made and in combination with other diagnostic methods such as interleukins and procalcitonin. (Hofer et al., 2012) In the Santa Barbara Integrated Hospital, the CPR performed in the first 24 hours of life has very low PPV, NPV, sensitivity and specificity, however, PPV increases from 5 to 85 $\%$ in the control CPR performed at 48 hours, and the sensitivity increases from 5.5 to $94 \%$. This indicates that the CPR at $48 \mathrm{~h}$ has a high possibility of detecting NB with EONS. With the inconvenience, that if the newborn is healthy, he must stay two to three days obligatorily in the hospital while the exams are done, increasing the expenses for the relatives and for the hospital. In a study by Roig et al. (2009) it was found that the PCR presented $50 \%$ PPV and sensitivity of $54.55 \%$, these results are below those found for the $48 \mathrm{~h}$ control CPR of this investigation.

In recent years, procalcitonin has emerged as a reliable marker of neonatal sepsis, however due to its high cost, its use is limited in developing countries (Adib et al., 2012). In Honduras public hospitals, access to procalcitonin is difficult until now, however, it would be important to make cost-benefit studies, as not only avoiding unnecessary hospital admissions, but avoiding them Complications in newborns.

Blood culture continues to be the gold standard for the diagnosis of EONS. However, it may present false negatives and in most cases a pathogenic microorganism is not isolated (Mally et al., 2014; Chiesa et al., 2015). 1484 cases of early neonatal sepsis were identified by Schrag et al. (2016) in a study conducted in California and Georgia, finding that the most common germ was GBS (532) followed by $\mathrm{E}$ coli (368) and viridans streptococci (280). In contrast to the literature, in this study, of the 
20 infants with blood-borne infection in 6 (30 $\%)$, the isolated microorganism was Enterobacteria and 5 (25\%) reported E. coli. All of this may be due to the fact that in Santa Barbara Integrated Hospital, one of the limitations is the lack of supplies, so blood samples are generally not taken at birth until the control CPR is obtained.

Developing countries report a neonatal mortality from sepsis as high as $60 \%$; in the developed countries it is also high from 2.2 to 8.6 per thousand live births. (Fernández et al., 2010) The results of this research show that there were no deaths, which may be due to the size of the sample or to the fact that the hospital where the study was performed is a regional hospital that refer to a center of greater complexity the infants who present some type of complication, $11 / 23$, had a positive blood culture and $12 / 23$ a negative blood culture; Which indicates that having a negative blood culture is not indicative of tranquility.

\section{CONCLUSION}

The laboratory alternatives for the diagnosis of EONS in the Santa Barbara Integrated Hospital are few; the fundamental pillar for its diagnosis is the search for risk factors and clinical status of the patient. Initial C-reactive protein is of little use, however the results of this research show that positive predictive value and sensitivity increase significantly at 48 hours, which proves that it, is a late marker of infection. Despite the multiple complications due to neonatal sepsis, the evolution of the newborns was favorable and the majority went home without complications, no patient died in the neonatology room.

ETHICAL ASPECTS: Category one study, because the patient's life was not put at risk. During the year 2015, the hospital director, Dr. Jorge Peraza, was asked to do the research.

LICONA, R. T. S.; FAJARDO, D. G. E.; FERRERA, G. R. A. \& MAZARIEGOS, A. Sepsis neonatal de inicio temprano; Valor diagnóstico de algunas pruebas de laboratorio. Int. J. Med. Surg. Sci., 4(1):1109-1114, 2017.

RESUMEN: Sepsis neonatal temprana es aquella situación clínica derivada de la invasión y proliferación de bacterias, hongos o virus en el torrente sanguíneo del recién nacido (RN), que se presenta en las primeras 72 horas de vida. Determinar la utilidad diagnóstica de los exámenes de laboratorio que se realizan a los RN con sospecha de sepsis neonatal temprana, en el Hospital Santa Bárbara Integrado (HSBI), Honduras. Se realizó un estudio de casos y controles, durante el año 2016, los casos fueron 20 RN con sepsis neonatal temprana comprobada por hemocultivo y los controles 40 RN que ingresaron como potencialmente sépticos, pero el resultado de hemocultivo fue negativo. Se calculó sensibilidad, especificidad, valor predictivo positivo (VPP) y negativo (VPN) de leucocitosis, plaquetas, proteína C reactiva (PCR) inicial y la de control. Los datos fueron analizados con el programa SPSS versión 19. Se encontró que 17 (28.3 \%) RN eran mujeres y $43(71.7 \%)$ hombres. El VPP de la PCR inicial fue $5 \%$, aumentando a $85 \%$ en el estudio de control. El microorganismo aislado fue enterobacter en 6 (30\%) de los RN. De los 23 (38.3 \%) neonatos que presentaron complicación; 11 (48 \%) tenían hemocultivo positivo y 12 (52 \%) tenían hemocultivo negativo. La condición de egreso fue alta médica en 55 (92\%) y referido a un hospital de mayor complejidad 5 ( 8 \%) de los neonatos. El VPP, de la proteína C reactiva, aumenta considerablemente al hacer un control laboratorial, entre 24-48 horas.

PALABRAS CLAVE: Laboratorios, Recién Nacido, Sepsis.

\section{REFERENCES}

Adib, M.; Bakhshiani, Z.; Navaei, F.; Saheb Fosoul, F.; Fouladi, S. \& Kazemzadeh, H. Procalcitonin: a reliable marker for the diagnosis of neonatal sepsis. Iran. J. Basic Med. Sci., 15(2):777-82, 2012. 
Arunachalam, A. R. \& Pammi, M. Biomarkers in earlyonset neonatal sepsis: An update. Ann. Clin. Med. Microbiol., 1(2): 1007, 2015.

Bhandari, V. Effective biomarkers for diagnosis of neonatal sepsis. J. Pediatr. Infect. Dis. Soc., 3(3):234-45, 2014.

Birju, B. A. \& Padbury, J. F. Neonatal sepsis: an old problem with new insights. Virulence, 5(1):1708, 2014.

Chiesa, C. ; Pacifico, L. ; Osborn, J. F. ; Bonci, E. ; Hofer, N. \& Resch, B. Early-onset neonatal sepsis: Still room for improvement in procalcitonin diagnostic accuracy studies. Medicine (Baltimore), 94(30):e1230, 2015.

Fernández, D. N.; de Estrada, R. J. D. \& Díaz, C. F. Morbilidad y mortalidad por sepsis neonatal precoz. Rev. Cuba. Pediatr., 82(2), 2010. Disponible en: http://scielo.sld.cu/ scielo.php?script =sci_arttext\&pid=S003475312010000200003

Mally, P. ; Xu, J. \& Hendricks-Munoz, K. D. Biomarkers for neonatal sepsis: Recent developments. Res. Rep. Neonatol., 4:157-68, 2014.

Hofer, N.; Zacharias, E.; Müller, W. \& Resch, B. An update on the use of C-reactive protein in earlyonset neonatal sepsis: current insights and new tasks. Neonatology, 102(1):25-36, 2012.

Licona, R. T. S.; Fajardo, D. G. E.; Ferrera, G. R. A. \& Hernández, O. A. G. Clinical and epidemiological characteristics in newborns with early sepsis. Integrated Santa Bárbara Hospital. Int. J. Med. Surg. Sci., 3(3):903-8, 2016.

Pérez, R. O.; Lona, J. C.; Quiles, M. ; Verdugo, M. A. ; Ascencio, E. P. \& Benítez, E. A. Sepsis neonatal temprana, incidencia y factores de riesgo asociados en un hospital público del occidente de México. Rev. Chil. Infectol., 32(4):447-52, 2015.

Roig, A. T.; Martínez, E. A.; Santurio, G. A. \& Fernández, R. A. J. Valor predictivo de algunos exámenes de laboratorio clínico en la infección neonatal bacteriana precoz. Rev. Cuba. Pediatr., 81(2), 2009. Disponible en: http://scielo.sld.cu/ scielo.php?script =sci_arttext \&pid=S0034$75312009000200001 \& \mathrm{lng}=\mathrm{es} \& \mathrm{nrm}=$ iso

Schrag, S. J.; Farley, M. M.; Petit, S.; Reingold, A.; Weston, E. J.; Pondo, T.; Hudson Jain, J. \& Lynfield, R. Epidemiology of invasive early-onset neonatal sepsis, 2005 to 2014. Pediatrics, 138(6):e20162013, 2016.

Secretaria de Salud de Honduras. Normas Nacionales para la Atención Materno-Neonatal. Tegucigalpa, Secretaria de Salud de Honduras, 2010.

Simonsen, K. A.; Anderson-Berry, A. L.; Delair, S. F. \& Davies, H. D. Early-onset neonatal sepsis. Clin. Microbiol. Rev., 27(1):21-47, 2014

Stoll, B. J.; Hansen, N. I.; Sánchez, P. J.; Faix, R. G.; Poindexter, B. B.; Van, Meurs, K. P.; Bizzarro, M. J. ; Goldberg, R. N.; Frantz, I. D. 3rd; Hale, E. C. ; Shankaran, S.; Kennedy, K.; Carlo, W. A.; Watterberg, K. L.; Bell, E. F.; Walsh, M. C.; Schibler, K.; Laptook, A. R.; Shane, A. L. ; Schrag, S. J.; Das, A.; Higgins, R. D. \& Eunice Kennedy Shriver National Institute of Child Health and Human Development Neonatal Research Network. Early onset neonatal sepsis: the burden of group B Streptococcal and E. coli disease continues. Pediatrics, 127(5):817-26, 2011.

Swarnkar, K. \& Vagha, J. Sepsis biomarkers in early onset neonatal infections: A review. Internet $J$. Infect. Dis., 11(1):1-9, 2013.

Corresponding author:

Tania Soledad Licona Rivera

Pediatrician, Santa Barbara Integrated Hospital.

Faculty University School of Health Sciences

National Autonomous University of Honduras

Sula Valley. EUCS, UNAH-VS

HONDURAS

Email: tania_licona@yahoo.com.mx

Received: 17-02-2017

Accepted: 26-02-2017 